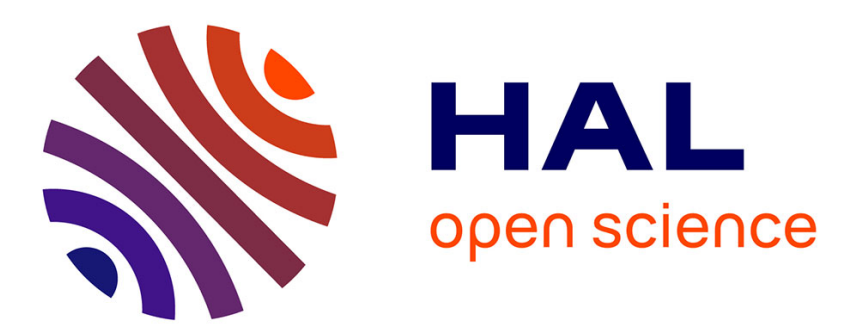

\title{
Demographic consequences of prey availability and diet of Red-billed Choughs Pyrrhocorax pyrrhocorax
}

\author{
Christian Kerbiriou, Romain Julliard
}

\section{To cite this version:}

Christian Kerbiriou, Romain Julliard. Demographic consequences of prey availability and diet of Red-billed Choughs Pyrrhocorax pyrrhocorax. Bird Study, 2010, 54 (3), pp.296-306. 10.1080/00063650709461489 . hal-02554702

\section{HAL Id: hal-02554702 \\ https://hal.science/hal-02554702}

Submitted on 28 Apr 2020

HAL is a multi-disciplinary open access archive for the deposit and dissemination of scientific research documents, whether they are published or not. The documents may come from teaching and research institutions in France or abroad, or from public or private research centers.
L'archive ouverte pluridisciplinaire HAL, est destinée au dépôt et à la diffusion de documents scientifiques de niveau recherche, publiés ou non, émanant des établissements d'enseignement et de recherche français ou étrangers, des laboratoires publics ou privés. 


\section{Demographic consequences of prey availability and diet of Red-billed Choughs Pyrrhocorax pyrrhocorax}

CHRISTIAN KERBIRIOU* and ROMAIN JULLIARD

UMR 5173 Muséum National d'Histoire Naturelle - CRBPO, 55 rue Buffon, 75005 Paris, France

Capsule Variation in prey availability appears to influence Chough fledging success and juvenile survival.

Aims To determine seasonal and annual variations in Chough prey and how these influence fledging success and juvenile survival.

Methods Chough faeces ( $\mathrm{n}=437,3905$ invertebrates) were collected year-round and analysed to determine diet composition. Seasonal and annual variation in prey abundance in Chough foraging habitat was assessed using pitfall trapping ( $\mathrm{n}=747,27124$ invertebrates) between 1996 and 2003. Fledging success was estimated for a population of 12 breeding pairs; juvenile survival was estimated by year-round resighting $(\mathrm{n}<2500)$ of individual birds that were colour-ringed as nestlings.

Results From April to June a high biomass of prey and a great variety of species were observed. Between July and October, both biomass and species diversity were reduced; prey consisted mainly of ants and a few beetle species. From November to March, biomass availability was intermediate, with the diet consisting mostly of Tipulidae larvae, plants and dung beetles. Chough juvenile monthly survival was low in August, November and December. Annual variation in fledging success was correlated with prey biomass availability in May.

Conclusion Seasonal variation in the availability of prey species and their biomass influences Chough demography.

Short title: Chough's diet variation and possible consequence on its demography

Keywords: Pyrrhocorax pyrrhocorax, chough diet, prey availability, monthly survival, fledging success, capture-mark-recapture. 


\section{INTRODUCTION}

The most frequently reported threat to European bird species is habitat change resulting from the intensification of agricultural practices (Benton et al. 2003, Krebs et al. 1999, Pain \& Pienkowski 1997, Shrubb 1993, Stoate et al. 2001, Tucker 1993, Tucker \& Heath 1995). However, agricultural abandonment can also result in declines in farmland bird populations (Bignal 1991). This may be particularly true for Red-billed Choughs Pyrrhocorax pyrrhocorax, a species closely associated with low-intensity agricultural habitats such as grazed rough grass and permanent pastures (Warnes 1982, McCracken et al. 1992, Rolando et al. 1994, Bignal et al. 1996, Madders et al. 1998, Robertson et al. 1995, Blanco et al. 1998). Intensification and abandonment of agricultural practices have been suggested as important factors leading to declines in Chough populations and their eventual extinction in parts of western Europe in the second half of the 20th century (Rolfe 1966, Garcia-Dory 1983, Kerbiriou 2001, McCracken et al. 1992, Meyer et al. 1994, Dendaletche 1991, Blanco et al. 1998). At the local scale, conservation managers are often confronted with a decrease in grazing pressure and an increase in abandoned land (Ravayrol 1995, Kerbiriou \& Le Viol 1999, Webber 2002, McCanch 2000). Several studies focusing on Chough diet have shown that these birds can use a great variety of surface-active insects; however, most studies outlined the importance of dung-associated insects, which appear to be one of the main components of Chough diet in spring, late summer and autumn (Warnes \& Stroud 1989, McCracken et al. 1992, McCracken \& Foster 1993). Some of these studies also pointed out the importance of cereals in the diet of Choughs, especially in autumn and winter (Warnes \& Stroud 1989, McCracken et al. 1992). Choughs are distributed from North Africa to central Asia. In western Europe, Chough populations are rare and exhibit a local and patchy distribution which appears to be related to a lack of suitable nesting sites (mainly cavities in cliffs) together with feeding areas characterized by open vegetation with low cover (Robert 1983, Faringha 1991, Rolando et al. 1994, Bignal et al. 1996, Blanco et al. 1998). The small western French population of Choughs is now confined to a few sites in Brittany and appears to be one of the smallest and most isolated Chough populations of western Europe (Tucker \& Heath 1995, Kerbiriou 2001). This population decreased from probably 100-150 pairs in the 1960 s to about 30 in the 1980s; presently it seems to have stabilized at 39-55 breeding pairs scattered in five population cores (Kerbiriou et al. 2005). The Breton population of Choughs inhabit coastal cliffs and feed in cereal fields and sheep pastures on the coast. The increase in abandoned agricultural land in the 1960s has apparently led the remaining Chough population to use a greater proportion of natural habitats, such as maritime grassland and coastal 
heathland, which are probably similar to the habitats used before the emergence of agriculture. We conducted a study on the seasonal and annual variation in prey availability in these Breton coastal habitats with the aim of identifying key prey types and determining how their abundance affects the Chough population.

\section{METHODS}

\section{Study area}

The study was conducted in Ouessant, a small island (1541 ha) located $20 \mathrm{~km}$ west of the western tip of Brittany, France $\left(48 \square 28^{\prime} \mathrm{N}, 5 \square 5^{\prime} \mathrm{W}\right)$. Holding 13 breeding pairs, Ouessant appears to be one of the core populations of Brittany; the nearest population (four or five pairs) occurs on the mainland, $22 \mathrm{~km}$ away from the island. The number of breeding pairs on Ouessant has remained stable over the last 50 years but the total population size has decreased from about 80 individuals to 50 during that period. Humans exploited the whole island until the early 20th century, after which the population declined severely; this led to the complete disappearance of cultivated fields after 1970 and a progressive reduction in sheep grazing, from 4500 sheep in 1950 to 650 in 2000. As a result, pastures have been undergrazed and the area of abandoned agricultural land has increased, especially on the coastal strip. Today, abandoned agricultural lands, dominated by Bracken Pteridium aquilinum and Brambles Rubus fructicosus, cover more than half of the island (Gourmelon et al. 2001). Extensive sheep grazing in central areas of the island is the only remnant of traditional agriculture (Gourmelon et al. 2001). Currently, one-third of Ouessant is occupied by pasture dominated by Dactlylis glomerata, Holcus lanatus, Trifolium repens, and Lolium perenne; vegetation height ranges between 10 and $40 \mathrm{~cm}$. In winter, sheep are free to wander and are sometimes seen grazing near the coastline. All remaining pastures appear undergrazed and unsuitable for Chough, as less than $1 \%$ of observations of feeding Choughs occur in this habitat (Kerbiriou et al. 2006). Choughs feed essentially in coastal vegetation and especially in low coastal turf. This vegetation, which grows on soil less than $15 \mathrm{~cm}$ thick, contains low plants (generally $<5$ $\mathrm{cm}$ high) and covers 62 ha, i.e. less than $5 \%$ of the total area of Ouessant. Low coastal turf is characterized by rocky outcrops and is dominated by Agrostis stolonifera maritima, Armeria maritima, Bromus ferroni, Catapodium loliaceum, Centaurium erythraea, Festuca rubra pruinosa, Isoetes histrix, Jasione montana, lichens (Cladonia sp.), Ophioglossum lusitanicum, Plantago coronopus, Sedum anglicum and Scilla verna. Most of these species have an early spring or even a winter cycle, i.e. they grow and (with the exception of perennial species) reproduce early and generally disappear during the dry period of summer. This vegetation is 
kept short by environmental constraints such as wind, sea spray, thin soil and human trampling (Kerbiriou \& Le Viol 1999).

\section{Data collection and statistical treatments}

Faecal analysis

The majority of Chough faeces (359 samples) were collected from sites where birds were seen eating, while a small proportion were collected at night roosting sites (15 faecal samples in June) or close to nests, mainly during ringing operations (six samples in April, 38 in May and 19 in June). A total of 437 samples were analysed (Table 1), with most collected in 1996 and a small number $(n=59)$ collected in May each year between 1997 and 2001. Each faecal sample was moistened and examined with a binocular microscope (1.5-4 $\square \square 10$ magnification). The animal, plant and mineral fractions were separated and identified. Using a reference collection of arthropods obtained by pitfall trapping in Chough foraging areas, the minimum number of individuals of each taxon present in each sample was estimated. Ants (Formicidae) were mainly identified from their heads, Coleoptera from their heads, mandibles, legs and elytra and Dermaptera from their cerci. Adult Diptera were identified from their wings, and larvae from posterior spiracles and mouthparts. The presence of adult Lepidoptera was detected by their wing scales. Spiders were identified from their head capsules and genitalia. Arthropod abundance in foraging habitats To assess monthly variations in arthropod prey availability in Chough feeding habitats, permanent pitfall traps were placed and checked every month: in 1996, ten traps were placed at each of six locations for 12 months (providing 683 usable samples). Pitfall trap sites were chosen according to the main Chough feeding areas. Subsequently, five traps were placed at one of the 1996 locations for ten months in 1997 (providing 44 usable samples), and from mid-April to mid-May in each of 1998, 2001, 2002 and 2003 (providing five usable samples each year). Field sampling was not performed in 1999 and 2000 due to lack of available time. All invertebrates collected were identified and counted (23 345 invertebrates in 1996; 2281, 321, 683, 948 and 867 in 1997, 1998, 2001, 2002 and 2003, respectively). A subsample $(n>30)$ of each invertebrate species caught was weighed (fresh weight) to allow an estimate to be made of the total biomass caught by pitfall in each habitat. Pitfall trapping is a widely used method to assess soil-surface activity of invertebrates (Greenslade 1964, Adis 1979, Luff 1975). The number of animals caught is known to depend both on invertebrate density and activity (Mitchell 1963, Crawford et al. 1995) and thus does not yield completely accurate estimates of prey availability. However, it is a cheap and labour-saving method that offers a valuable means of monitoring soil-surface 
invertebrates (Luff 1975, Den Boer 1985). Results from pitfall traps have been compared to exhaustive sampling on standardized squares to assess the accuracy of the pitfall trapping method. In the latter method, all invertebrates found in vegetation and in the first $2 \mathrm{~cm}$ of soil on a $50 \square \square 50 \mathrm{~cm}$ square were collected manually and provided an accurate estimate of invertebrate density (Canard 1982). In the current study, similar sampling was conducted on five different squares each month between February and May 1997 (in April, only four squares were sampled) near the pitfall trap locations. Monthly variation in prey availability was analysed using analysis of variance.

\section{Estimation of Chough demographic parameters}

The Ouessant breeding Chough population was systematically surveyed from 1996 to 2003 (about 13 breeding pairs each year) and the number of fledglings determined for each nesting attempt. Between 1998 and 2003, all accessible juveniles were colour-ringed before fledging ( $n=73,67 \%$ of fledglings). Juvenile survival was estimated from resighting records (based on year-round resighting, about 2500 records), using the MARK program (White \& Burnham 1999). The model selections approach used in this program identifies the factors (e.g. month and year of birth) statistically associated with survival and resighting rates. To select the best model, we used Akaike's procedure (Burnham \& Anderson 1998), which allows comparison of non-nested models according to their Akaike information criterion (AIC) corrected for small sample size. Models with low AICc are considered a good compromise between parsimony (low number of parameters in the model) and adequate fit to the data (low deviance). The AIC weight indicates the relative likelihood of each model given the data, and gives the probability that the real model occurs among those considered for model selection (Burnham \& Anderson 1998, Lebreton et al. 1992). The variables used to model variation in juvenile resighting were month and year of birth. Because of the extremely high resighting rate, the disappearance date of any individual could be assessed to the nearest month (i.e. individuals not recorded for more than 30 days were never seen again on the island). A similar colour-ringed programme was launched in the nearest mainland population to detect possible exchanges of individuals. Ouessant monthly juvenile survival was thus estimated using 'known fate' models implemented in the MARK program. Known fate data assume that there are no nuisance parameters involved in bird resightings and that the probability of encountering any living individual on each occasion (i.e. each month) is 1. June survival rate accounts for nest survival of old chicks during about 19 days (from ringing day, which occurred approximately three weeks after hatching, to fledging day). Fledging occurs around 
mid-June. Finally, we tested the correlation between interannual variation in prey availability and fledging success. Prey biomass records, collected at the same pitfall location in May 1996, 1997, 1998, 2001, 2002 and 2003, were correlated to the fledging success of the corresponding year using analysis of variance. The analysis also accounted for a possible effect of nest on fledging success; prey biomass effect was nested into the year effect.

\section{RESULTS}

\section{Food types}

The 437 faecal samples contained 3905 individual invertebrates. A total of 52 invertebrate prey species were identified. Plants were detected only in autumn and winter. The plant fraction was mainly wild grains (>90\%) and some bulbs of Scilla verna; plants generally represented a negligible fraction of droppings, but could reach up to 57\% in December (Table 1). The analysis of prey remains showed important seasonal variations (Table 1, Fig. 1): diet in spring consisted mainly of Coleoptera, spiders, ants and Diptera (mostly Tipulidae larvae), whereas in summer the diet was dominated by ants. In autumn, ants occurred together with beetles and plants. In winter, flies (Tipulidae larvae) contributed a great part to the diet composition. To investigate seasonal variation in diet composition in greater detail, a principal component analysis (PCA) was used to analyse frequency of occurrence of prey in the 437 faecal samples (Fig. 2). The two first axes of this PCA explained $26.7 \%$ and $18.2 \%$ of the variance, respectively. The analysis isolated three groups. (i) The summer-early autumn group (July to October) consisted mainly of ants Lasius flavus and Myrmica sabuleti, ant eggs and Coleoptera Calathus melanocephalus, Steropus madidus, Amara aenea. (ii) The late autumnwinter group (November to March) consisted mainly of Tipulidae larvae, plants, dung beetles (Aphodius spp., Onthophagus spp., Thyphoeus thyphoeus, carabidae beetle Leistus fulvibarbis, Cymindis axillaris, Nebria brevicollis and weevil Oniscus asellus. (iii) The spring group (April to June) included numerous species with spring activity, such as Coleoptera Rhyzotrogus aestivus, Cetonia maura, Cetonia aurata, Hister quadrimaculatus, Adelocera murina, Agriotes gr-lineatus and also spiders, such as Lycosidae Trochosa terricola, Pardosa sp. We then considered variation in the type of prey occurring in Chough diet during the three time periods. Invertebrates were assigned to one of three classes according to their ecology: (i) the 'burrower' group, including species such as beetle larvae, Tipulidae larvae and dungdwelling species; (ii) the 'walker' group, including species with important soil activities such as Lycosidae spiders, Carabidae beetles and ants; (iii) the 'other' group, including species waiting in ambush for their prey, such as Thomisidae spiders. Choughs generally captured 
mainly invertebrates of the 'walker' group, except during the winter period when burrowers represented nearly half of the prey, Table 2).

\section{Prey availability}

Variation in invertebrate biomass, as assessed by pitfall trapping adjusted to month, appeared to be correlated with monthly invertebrate biomass as estimated via the exhaustive method $(F 1,14=5.59, P<0.032, r 2=0.84)$. All species known to occur in Chough faeces (Table 1$)$, as well as any similar species collected in the pitfall traps, were considered as potential Chough prey; for example if only Drassodes cupreus remains were found in Chough faeces, all spider species of the genus Drassodes were considered as potential prey. Some species found in pitfall traps and not in faeces were not considered as prey; these were essentially very small species such as Acritus homeopathicus beetles (size $<1 \mathrm{~mm}$ ) or Liniphiidae spiders, or large species such as Megadontus purpurescens beetles. Prey availability in 1996 varied between months $(F 11,55=7.23, P<0.0001)$ and significant variations were also detected across pitfall stations $(F 5,66=2.82, P=0.02)$. On average, invertebrate prey biomass reached a maximum in spring and decreased to a low level in November and December; a similar pattern was observed in 1997 based on data drawn from a smaller sample (Fig. 3).

\section{Key period for juvenile mortality}

The monitoring of Chough reproduction phenology on Ouessant indicated that egg-laying occurred around mid-April and that juveniles fledged around mid-June (14 June \pm 1 day, $n=$ 73 nests). The juveniles were left to feed themselves mainly from late July/August onwards. The analysis of juvenile resighting data focused on juvenile survival rates by month, to investigate whether there were any consistent key periods for juvenile mortality. Between 1998 and 2003, only two colour-ringed Choughs were resighted outside Ouessant. They were detected together in August 2001 after being last seen in Ouessant in July 2001. These two ringed birds were subsequently resighted many times by at least five independent observers within four months. The same was true for the mainland population, where colourmarked birds $(n=10)$ were resighted often but never recorded on Ouessant. This indicates that although dispersal outside Ouessant is possible, it is rare, and that observation pressure on Chough habitat is sufficient that such dispersal events are unlikely to remain undetected. Variation in juvenile survival was studied by ringing birds in nests in mid-May and recording resighting of those birds until June of the following year. The AICc in Table 3 indicated that the most parsimonious model included additive effects of month and year (equivalent to 
cohort) on juvenile survival. Yet, the goodness-of-fit test $(\chi 2=37.32$, $\mathrm{df}=18, P=0.005)$ indicated a significant deviance from the full model, indicating that an additional source of variationin survival remained to be identified. Monthly survival variation of Choughs in their first year (from ringing day in May to June of the next year, i.e. 13 months) identified two crucial periods during which survival rates were low: August (survival rate $=0.57$ ) and November-December (survival rates $=0.81$ and 0.69) (Fig. 4). Other months were characterized by high survival rates, ranging from 0.95 to 1.00 (Fig. 4). Fledging success varied across years, from 0.69 to 1.62 juveniles/pair with an average of $1.45 \pm 0.13$. The relationship between fledging success and prey availability in May 1996, 1997, 1998, 2001, 2002 and 2003 was analysed to determine whether there was any consistent relationship (Fig. 5). Yearly fledging success appeared to be influenced by nest-site $(F 16,5=4.92, P<0.0001)$ and fledging success adjusted to nest and year appeared to be influenced by variation in prey biomass (prey biomass effect nested to year effect $F 1,4=22.60, P=0.009$ ). No influence of major prey groups was detected on fledging success adjusted to nest (beetles: $F 1,4=0.49, P=$ 0.52 ; spiders: $F 1,4=2.18, P=0.21$; ants: $F 1,4=1.94, P=0.24)$.

\section{DISCUSSION}

\section{Diverse diet of Choughs on Ouessant}

Some studies have found Red-billed Choughs to be almost exclusively insectivorous (Matvejev 1955, Rolfe 1966, Meyer 1990, Sanchez-Alonzo et al. 1996), while in other locations they have been found to have a diet containing a mixture of plants and animals, with more insects taken during the breeding season and summer, and more plants taken in autumn and winter (Warnes \& Stroud 1989, McCracken et al. 1992, Blanco et al. 1993, Soler \& Soler 1993, Meyer et al. 1994). Some authors have suggested that changes in diet are due to a decrease in the availability of insects in autumn and winter (Garcia-Dory 1983, Soler \& Soler 1993). This was found to be the case in Ouessant, where the consumption of plants occurred in winter months when insect prey biomass was at its lowest. As found in other studies (Warnes \& Stroud 1989, McCracken et al. 1992, Soler \& Soler 1993, Meyer et al. 1994), this study indicated that adult beetles are one of the most important prey items for Choughs on Ouessant. Some beetles occur in the diet in large proportions, such as Amara aenea in summer, or Rhyzotrogus aestivus, Cetonia aurata, Agriotes gr-lineatus, Adelocera murina and Hister quadrimaculatus in spring. Conversely, very few species of adult beetle occurred in Chough diet in winter: Typhoeus typhoeus appeared to be an important prey during this period. T. typhoeus is often associated with rabbit colonies and their dung (D.I. McCracken 
pers. comm.) On Ouessant rabbits occurred mainly on abandoned agricultural land but could also be seen on the coast and could be an additional source of this prey for Choughs. Other coleoptera were essentially represented by larvae. Dung beetles (scarabs Aphodius spp., Onthophagus spp., Geotrupes pyrenaeus, Typhoeus typhoeus) represented a very small component of the Chough diet in Ouessant and occurred mostly in winter. This observation contrasts with most other studies which have found dung beetles to be a major food source for Choughs, e.g. on Bardsey Island, Wales (Roberts 1982, 1983), Pembrokeshire, Wales (Meyer et al. 1994), Cornwall, England (Meyer 1990), Islay, Scotland (Warnes 1982, McCracken \& Foster 1993, McCracken et al. 1992, Warnes \& Stroud 1989), the Italian Alps (Laiolo \& Rolando 1999), and Sar-plania and Perister, former Yugoslavia (Matvejev 1955). In those studies, Aphodius species occurred in Chough diet nearly all year round and often represented more than $90 \%$ of Chough prey. Conversely in Ouessant Aphodius appeared only in late autumn and winter, represented only $4 \%$ of prey identified in those months, and occurred in an average of only $17 \%$ of faecal samples analysed in the same months. This relatively rare occurrence of dung beetles in Chough diet in Ouessant is probably connected with the very low frequency with which Choughs are observed feeding on sheep-grazed pastures, a typical habitat for Aphodius. This avoidance of pastures could be explained by vegetation height, which often ranges from 10 to $40 \mathrm{~cm}$ due to the low grazing pressure in pastures on Ouessant. Habitat attractiveness for Choughs is known to decrease with increasing vegetation height and the Chough selectivity coefficient for sward height has been found to be zero or negative above $10 \mathrm{~cm}$ (Whithead et al. 2005, Kerbiriou et al. 2006). In addition, the presence of dung beetles in Chough diet in autumn and winter on Ouessant is very likely linked to the particular sheep-grazing practices: in this season, sheep are left grazing freely on the island, and sometimes graze on coastal habitat. Hence, on Ouessant, dung beetles are available on coastal habitats only during this period and probably only in small numbers. This study also underlined the importance of ants Lasius flavus and Myrmica sabuleti which appeared to be the main food source from late spring to early autumn. In other studies, the importance of ants in Chough diet varied from total absence (Warnes \& Stroud 1989) to the status of regular prey (most studies) or even major food source (Cowdy 1973).

\section{Diet at key periods of juvenile mortality}

The analysis of monthly survival of juveniles during their first year identified three crucial months: August, November and December. On Ouessant, a high level of invertebrate biomass and a great variety of species occurred from the beginning of the nestling period through the 
time of juvenile fledging. This could partly explain the high survival rates of juveniles observed during this period. By contrast the amount of invertebrate biomass and the spectrum of prey species decreased during the summer. This was especially true in August, coinciding with the period when juveniles are left to feed themselves, when on Ouessant Choughs seem to depend mainly on ants and to a lesser extent on a few beetles such as Amara aenea, Steropus madidus and Calathus melanocephala. Emancipation of juveniles is known to be a period of high mortality in many bird species. This effect is reinforced in Ouessant, as emancipation occurs not only during a period when available prey biomass is greatly decreased, but also at a time when tourism disturbances are high (Kerbiriou et al. submitted). August juvenile survival is noticeably lower in Ouessant than on the island of Islay, UK (Bignal et al. 1987, Kerbiriou et al. submitted) where studies have highlighted that newly fledged birds and subadults depend heavily on easily obtained prey items associated with livestock dung (McCracken et al. 1992). Prey biomass reached its lowest level in November and December, when juvenile Chough survival was also found to be low. However, it should be noted that prey biomass in November and December was still comparable to (although a little lower than) that in September and October, when juvenile survival was much higher. Hence, prey biomass might not be the only factor responsible for the low survival rates during November and December. At this time, a strong qualitative change in prey availability occurs, in terms not only of the species availability but also of where these species occur (Table 2). The need to change to a different foraging strategy may also contribute to increased juvenile mortality, as juveniles focus on 'walker' species during summer, but then must complement their diet with 'burrower' species during the late autumn and winter. Tipulidae larvae (a burrower species) appear to be one of the main prey taken during this period, as previously observed in Islay (McCracken et al. 1992), Ramsey Island (Meyer et al. 1994), Bardsey Island (Roberts 1982) and in western Ireland (Morgan 1971). Plants also appeared in Chough diet on Ouessant at that time, and this marked change in diet probably induces important changes in foraging behaviour and could also contribute to the reduction in juvenile survival. In Ouessant, monthly juvenile survival rates during November and December are lower than those in Islay, UK (Bignal et al. 1987). One possible explanation for this could be that young birds in Ouessant are not used to the specific foraging behaviour necessary to obtain burrowing prey items. According to the diet composition during June and July (Warnes \& Stroud 1989) and foraging behaviour on Islay (Bignal et al. 1997), non-emancipated juveniles in this Scottish island probably learn from their parents how to obtain invertebrates from the soil and from dung. Similar observations were made in Spain, where young Choughs appeared 
to be fed by their parents mainly with burrower prey items (Sanchez-Alonzo et al. 1996). In addition, unlike on Islay, Choughs in Ouessant cannot forage on cereal grains since cropping on the island disappeared 50 years ago. Fledging success may also be influenced by feeding resources. Fledging success seemed to be influenced by total prey biomass availability rather than by the biomass of a specific prey group; this could be explained by the great diversity of spring invertebrates available. Compared to estimates of Chough fledging success at other locations, fledging success on Ouessant appeared to be among the lowest, regardless of whether fledging success of the whole population $(1.37 \pm 0.14$ se at Ouessant; 2.02 in Reid et al. 2003; 1.88 to 2.85 in Bullock et al. 1983) or fledging success of successful breeders (2.48 \pm 0.11 se at Ouessant; 2.68 in DeSanctis et al. 1997; 2.60 in Laiolo \& Rolando 2001) is considered. Fledging success is a combination of the breeding pair's 'quality' (e.g. female body condition, parental care experience) and the amount of food brought to the nest. Juvenile mortality in June (i.e. the three last weeks in the nest and the first days after fledging) was found to be rather low on Ouessant. Thus, the variation in fledging success could be influenced either by chick survival at an early stage or by female physiological condition (Reid et al. 2003). However, insufficient information is available to allow us to discriminate between these two hypotheses on Ouessant. Furthermore, the period influencing female body condition is unknown. Nevertheless, May, the feeding period of early chicks, appeared to be a potentially crucial period as prey biomass availability at this period influences fledging success.

\section{Conclusion}

This study highlights that on Ouessant prey biomass availability affects Chough demographic parameters such as fledging success and, most likely, juvenile survival in the first year after fledging. In addition, Chough diet appeared to be dominated by very few prey species, which put constraints on juvenile survival during periods when those prey species were absent or rare. This relationship probably affects the viability of the very small Chough population in Brittany. However, further detailed information is needed before it is possible to quantify the consequences of fluctuations in these key prey items on juvenile Chough survival, or to understand how fluctuations in prey availability are related to environmental changes. To this end, further detailed studies of annual variation in prey availability during August, November and December are required.

\section{ACKNOWLEDGEMENTS}


Special thanks are due to Jean-Yves Monat and Jacques Nisser for help with ringing techniques. We thank the following persons for sightings of marked Choughs: A. Audevard, M. Champion, D. Cohez, F. Duruz, P. Gaultier, Y. Jacob, J. P. Jordan, D. Laloi, V. Le Pennec, I. Le Viol and D. Matti. We thank G. Tiberghien, I. Le Viol and V. Le Pennec for valuable help in identification of invertebrates, and F. Jiguet for help in PCA analysis. We thank Frédéric Bioret for assistance in the realization of botanical typology of the Chough habitat, and Emmanuelle Porcher, Peter Vickery and Davy McCracken for insightful comments and discussion on earlier drafts of this manuscript.

\section{REFERENCES}

Adis, J. 1979. Problems of interpreting arthropod sampling with pitfall traps. Zool. Anz. 202: 177-184.

Benton, T.G., Vickery, J.A., \& Wilson, J.D. 2003. Farmland biodiversity : is habitat heterogeneity the key? TR.E.E $18: 182-188$

Bignal, E., Monaghan, P., Benn, S., Bignal, S., Still, E., and Thompson, P.M. 1987. Breeding success and post-fledging survival in the Chough (Pyrrhocorax pyrrhocorax). Bird Study 34, 39-42.

Bignal, E. 1991. Transhumance in Spain. In: Birds and pastoral agriculture in Europe. , ed. by D.J. Curtis, E.M. Bignal and D.I. McCracken, 18-21. Peterborough, Joint Nature Conservation Committee.

Bignal, E.M., McCraken, D.I, Stillman, R.A, \& Ovenden, G.N. 1996. Feeding behavior of nestling choughs in the Scottish Hebrides. J. Field Ornithol. 67: 25-43.

Bignal, E., Bignal S. \& McCracken D. 1997. The social life of the Chough. British Wildlife 8(6): 373-383.

Blanco, G., Fargallo, J.A. \& Cuevas, J.A. 1993. Consumption rates of olives by choughs in central Spain : variations and importance. J. Field Ornithol 65: 482-489. 
Blanco, G., Tella, J.L. \& Torre, I. 1998. Traditional farming and key foraging habitats for chough Pyrrhocorax pyrrhocorax conservation in a Spanish pseudosteppe landscape. Journal of Applied Ecology 35: 232-239.

Bullock, I.D., Drewett, D.R. \& Mickleburgh S.P. 1983. The chough in Britain and Ireland. British Birds 76: 377-401.

Burnham, K.P. \& Anderson, D.R. 1998. Model selection and inference, a practical information-theoretic approach Springer, New-York.

Canard, C. 1982. Essai d'étude écologique quantitative sur quelques groupes d'invertébrés épigés d'une lande sèche armoricaine. Bulletin d'Ecologie. 13 (1) : 49-64.

Cowdy, S. 1973. Ants as a major food source of the chough. Bird Study 20: 117-120.

Crawford, R.L., Sugg, P.M. \& Edwards, J. S. 1995. Spider arrival and primary establishment on a terrain depopulated by volcanic eruption at Mount St. Helens, Washington. The American Midland Naturalist 133 : 60-75.

Den Boer, P.J. 1985. Fluctuations of density and survival of carabid population. Oecologia 67 : 322-330.

Dendaletche, C. 1991. Alpine Chough and Choughs : biological integrators of agropastoralism ecosystems in the Pyrenees. In: Birds and Pastoral Agriculture in Europe (Eds Curtis D.J, Bignal E. and Curtis M.A) pp. 68-70

DeSanctis, A., De Marinis, F., Limongelli, L., Pellegrini, M. \& Spinetti, M. 1997. The status and breeeding biology of the chough (Pyrrhocorax pyrrhocorax Linnaeus) in the Central Apennines-Abruzzo-Italy. Avocetta 21: 157-164.

Faringha, J.C. 1991. Medidas urgentes para a conservaçào da Gralda de bico vermelho Pyrrhocorax pyrrhocorax em Portugal. Estudos de biologia e conservaçao da Natureza. 2. SNPRCN, Lisboa 47p. 
Garcia-Dory, M.A. 1983. Datos sobre la ecologia del genero Pyrrhocorax (P. pyrrhocorax y P. graculus) en el parque Nacional de la Montana de Covodonga, Asturias. Alytes 1: 411-448.

Gourmelon, F., Bioret, F. \& Le Berre, I. 2001. Historic land-use changes and implications for management of a small protected island". Journal of Coastal Conservation 7: 41-48.

Greenslade, P.J.M. 1964. Pitfall trapping as a method for studying population of Carabidae (Coleoptera). J. Anim. Ecol. 33: 301-310.

Kerbiriou, C. \& Le Viol I. 1999. Landscape management for the Chough, Porz Gwenn (Isle of Ouessant, France) in Chough and Farming Seminar. Isle of Islay, 15-16 September 1999 : $32-42$

Kerbiriou, C. 2001. Originalité de la population bretonne de crave à bec rouge dans un contexte européen. Alauda, 69: $2001:$ 25-42

Kerbiriou, C. Thomas A., Floc'h P., Beneat Y., Floté D., Gager L., \& Champion M. 2005. Recensement 2002 de la population bretonne de crave à bec rouge (Pyrrhocorax pyrrhocorax). Ornithos 12: 113-122.

Kerbiriou, C., Gourmelon F., Jiguet F., Bioret, F. Le Viol I. \& Julliard R. 2006 Linking territory quality and reproductive success in the chough (Pyrrhocorax pyrrhocorax): implications for conservation management of an endangered population. Ibis 148: 352-364

Kerbiriou, C., Gourmelon F., Le Viol I. \& Julliard R. in prep. Tourist impact on an endangered bird : from behavioural response of individuals to viability of the population. Submit at Biological Conservation.

Krebs, J.R., Wislon, J.D., Bradbury, R.B. \& Siriwardena, G.M. 1999. The second silent spring? Nature 400 : 611-612. 
Laiolo, P. \& Rolando A., 1999. The diet of the chough (Pyrrhocorax pyrrhocorax) and the alpine chough (Pyrrhocorax graculus) in the alps: seasonality, resource partitioning and population density. Rev. Ecol. (Terre Vie) 54: 133-147.

Laiolo, P. \& Rolando, A. 2001. A comparative analysis of the breeding biology of the redbilled Chough Pyrrhocorax pyrrhocorax and the Alpine Chough P. graculus coexisting in the Alps. Ibis 143: 33-40.

Lebreton, J.-D., Burnham, K.P., Clobert, J., \& Anderson, D.R. 1992. Modelling survival and testing biological hypothesis using marked animals: a unified approach with case studies. Ecological Monographs 62: 67-118.

Luff, M.L. 1975. Some features influencing the efficiency of pitfall traps. Oecologia 19: 345357.

Madders, M., Leckie F.M., Watson J, \& McKay C.R. 1998. Distribution and foraging habitat preferences of Choughs on the Oa peninsula, Islay. Scottish Birds. 19: 280-289.

Matvejev, S.D. 1955. Le crave à bec rouge (Pyrrhocorax pyrrhocorax docilis GM.) en Yougoslavie. Acta Musei Macedonici Scientiarum Naturalium 4: 10-32.

McCanch N. 2000. The relationship between Red-Billed Chough Pyrrhocorax pyrrhocorax (L) breeding populations and grazing pressure on the Calf of Man. Bird Study 47: 295-303.

McCracken, D.I., Foster, G.M., Bignal, E.M. \& Bignal, S. 1992. An assessment of chough Pyrrhocorax pyrrhocorax diet using multivariate analysis technique. Avocetta 16: 19-29.

McCracken, D.I., Foster, G.M. 1993. Surface-active invertebrate communities and the availability of potential food for the Chough, Pyrrhocorax pyrrhocorax L., on pastures in north-west Islay Pedobiologia 37: 141-158.

Meyer, R.M. 1990. Observations on two Red-Billed Choughs Pyrrhocorax pyrrhocorax in Corwall: Habitat use and food intake. Birds Study 37: 199-209. 
Meyer, R.M, Buckland P.C. \& Monaghan P. 1994. The diet of the chough Pyrrhocorax pyrrhocorax as indicated by analysis of digested prey remains. Avocetta 18: 95-106.

Mitchell, B. 1963. Ecology of two carabid beetles, Bembidion lampros and Trechus quadristriatus. Studies on populations of adults in the field, with special reference to the technique of pitfall trapping. J. Anim. Ecol. 32: 377-392.

Monaghan, P. 1989. The background to Chough studies in Britain. In: Chough and land-use in Europe (Eds E. Bignal and D. J. Curtis) pp. 4-8.

Morgan, A. 1971. Chough digging for food in sand. British Birds 64: 422-423.

Pain, D.J. \& Pienkowski, M.W. 1997. Farming and birds in Europe. Academic Press, London.

PCNP (Webber, J.) 2002. A niche scheme tackling the decline of traditional management on Pembrokeshire's cliff-top and coastal slopes. Pembrokeshire Coast National Park.

Ravayrol A. 1995. Le crave à bec rouge sur le Larzac méridional. GRIVE. Life Nature Grand Causses. Montpellier

Reid, J.M, Bignal, E.M., Bignal, S., McCracken, D.I. and Monaghan, P. 2003. Environmental variability, life-history covariation and cohort effects in the red-billed chough. J. Anim. Ecol 72: 36-46.

Roberts, P.J. 1982. Food of the chough on Bardsey Island, Wales. Birds Study 29: 155-161.

Roberts, P.J. 1983. Feeding habitats of the chough on Bardsey Island (Gwynedd). Bird Study 30: $67-72$.

Roberts, P.J. 1985. The Choughs of Bardsey. British Birds, 78, 217-232. 
Robertson, A., Jarvis, A.M., \& Day, K.R. 1995. Habitat selection and foraging behavior of breeding choughs Pyrrhocorax pyrrhocorax L. in county Donegal. Proceeding of the Royal Irish Academy. 95:69-74.

Rolando, A. Patterson, I., Laiolo, P. 1994. The foraging behaviour of the chough Pyrrhocorax pyrrhocorax in two contrasting habitats Avocetta 18: 41-51.

Rolando, A. \& Laiolo, P. 1995. A comparative analysis of the diet of the Chough Pyrrhocorax pyrrhocorax and the alpine chough Pyrrhocorax graculus coexisting in the Alps. Ibis 139: 388-395.

Rolfe, R. 1966. Status of the Chough in Scotland. Scottish Birds 12: 238-246.

Sanchez-Alonzo, C., Ruiz, X., Blanco, G. \& Torre, I. 1996. An analysis of the diet of Redbilled Chough Pyrrhocorax pyrrhocorax nestling in NE Spain, using neck ligatures. Ornis Fennica 73: 179-185.

Shrubb, M. 1993. The Kestrel. Hamlyn Species Guides, Hamlyn London.

Soler, J.J. \& Soler, M. 1993. Diet of the Red-Billed Chough Pyrrhocorax pyrrhocorax in south-east Spain. Bird Study 40: 216-222.

Stoate, C., Boatman, N.D., Borralho, R.J., Carvalho, C.R., Snoo, G.R. \& Eden, P. 2001. Ecological impacts of arable intensification in Europe. Journal of Environmental Management. 63 : 337-365.

Tucker, G.M. 1993. Effects of agricultural practices on filed use by invertebrate-feeding birds in winter. Journal of applied Ecology 29: 779-790.

Tucker, G. M. \& Heath, M. F. 1995. Birds in Europe their conservation status. Cambridge, U.K. Birdlife Conservation serie 3600p.

Warnes, J.M. 1982. A study of the ecology of the Chough Pyrrhocorax pyrrhocorax L. on the isle of Islay, Argyll, 1980-1981. M.Sc. Thesis, University of Stirling. 
Warnes, J.M. \& Stroud, D.A. 1989. Habitat use and food of choughs on the island of Islay, Scotland. In: Chough and land-use in Europe (Eds E. Bignal and D. J. Curtis), pp. 46-51.

Whithead, S., Johnstone, I. \& Wilson, J.D. 2005. Choughs Pyrrhocorax pyrrhocorax breeding in Wales select foraging habitat at different spatial scales. Bird Study 52:193-203.

White, G.C. \& Burnham, K.P. 1999: Program MARK: survival estimation from populations of marked animals. Bird Study 46 (suppl.): 120-139. 


\section{LEGENDS TO FIGURES}

Table 1:Proportion of faecal samples analysed each month which contained each prey item.

\begin{tabular}{|c|c|c|c|c|c|c|c|c|c|c|c|c|c|c|}
\hline Taxon & $\begin{array}{l}\text { Moving } \\
\text { group }\end{array}$ & $\begin{array}{l}\text { Encoded } \\
\text { name }\end{array}$ & January & February & March & April & May & June & July & August & September & October & November & December \\
\hline Sample number & & & 34 & 16 & 40 & 58 & 107 & 35 & 32 & 40 & 24 & 6 & 31 & 14 \\
\hline PLANTS & & & 0,24 & 0 & 0,05 & 0 & 0 & 0 & 0 & 0 & 0 & 0,50 & 0,23 & 0,57 \\
\hline $\begin{array}{l}\text { OLIGOCHAETA } \\
\text { ARACHNIDA }\end{array}$ & Burrower & oligo & 0,06 & 0 & 0 & 0,05 & 0,01 & 0 & 0 & 0 & 0 & 0 & 0,03 & 0,07 \\
\hline Drassodes cupreus & Walker & dracup & 0 & 0 & 0 & 0,02 & 0 & 0 & 0 & 0 & 0 & 0 & 0 & 0 \\
\hline Trochosa terricola & Walker & troter & 0 & 0 & 0,03 & 0,07 & 0,01 & 0,03 & 0 & 0 & 0 & 0 & 0 & 0 \\
\hline Xystichus erraticus & Other & xyserr & 0 & 0 & 0 & 0 & 0,01 & 0 & 0 & 0 & 0 & 0 & 0 & 0 \\
\hline Dysdera spp & Other & dyssp & 0,03 & 0 & 0 & 0 & 0,03 & 0,06 & 0,06 & 0,05 & 0 & 0 & 0,03 & 0,21 \\
\hline Pardosa spp & Walker & parsp & 0 & 0 & 0 & 0 & 0,05 & 0 & 0 & 0 & 0,17 & 0 & 0 & 0 \\
\hline Indeterminate & Walker & arasp & 0,24 & 0,06 & 0,08 & 0,48 & 0,44 & 0,26 & 0,22 & 0,35 & 0,21 & 0 & 0,19 & 0,29 \\
\hline OPILINIDA & & & & & & & & & & & & & & \\
\hline $\begin{array}{l}\text { Homalenotus quadridentatus } \\
\text { CRUSTACEA }\end{array}$ & Walker & homqua & 0 & 0 & 0 & 0,02 & 0 & 0 & 0 & 0 & 0 & 0 & 0 & 0 \\
\hline $\begin{array}{l}\text { Oniscus asellus } \\
\text { MYRIAPODA }\end{array}$ & Walker & oniase & 0,03 & 0,06 & 0,03 & 0 & 0 & 0 & 0 & 0 & 0 & 0 & 0 & 0,14 \\
\hline Cylindroiulus latestriatus & Walker & iule & 0,03 & 0,19 & 0,08 & 0,04 & 0,01 & 0 & 0 & 0 & 0 & 0,17 & 0 & 0,14 \\
\hline $\begin{array}{l}\text { Lithobius forficatus } \\
\text { LEPIDOPTERA }\end{array}$ & Walker & litfor & 0,12 & 0 & 0,03 & 0,09 & 0,03 & 0,03 & 0,03 & 0,05 & 0,25 & 0 & 0,03 & 0,36 \\
\hline $\begin{array}{l}\text { Larvae } \\
\text { COLEOPTERA }\end{array}$ & Walker & larle & 0 & 0 & 0,05 & 0,11 & 0,04 & 0,29 & 0 & 0,03 & 0,04 & 0 & 0 & 0 \\
\hline Carabidae & & & & & & & & & & & & & & \\
\hline Amara aenea & Walker & amaae & 0 & 0 & 0,08 & 0,02 & 0,22 & 0,03 & 0,19 & 0,27 & 0 & 0 & 0,06 & 0 \\
\hline Anisodactylus binotatus & Walker & & 0 & 0 & 0 & 0 & 0 & 0 & 0 & 0 & 0 & 0 & 0 & 0 \\
\hline Calathus melanocephala & Walker & calmel & 0,03 & 0 & 0 & 0 & 0 & 0 & 0 & 0,14 & 0,33 & 0,33 & 0,10 & 0,07 \\
\hline Cymindis axillaris & Walker & cymaxi & 0,06 & 0,06 & 0,05 & 0 & 0 & 0 & 0 & 0 & 0 & 0 & 0 & 0,07 \\
\hline Cicindella campestris & Other & ciccam & 0 & 0 & 0 & 0 & 0,01 & 0 & 0 & 0 & 0 & 0 & 0 & 0 \\
\hline Steropus madidus & Walker & stemad & 0 & & 0,03 & 0 & 0,02 & 0,06 & 0,44 & 0,30 & 0,13 & 0 & 0 & 0 \\
\hline Poecilus cupreus & Walker & poecup & 0 & 0 & 0 & 0 & 0,02 & 0,03 & 0 & 0 & 0 & 0 & 0 & 0 \\
\hline Nebria brevicollis & Walker & nebre & 0,06 & 0 & 0,05 & 0,02 & 0 & 0 & 0 & 0 & 0 & 0 & 0 & 0,07 \\
\hline Harpalus rubripres & Walker & harrub & 0 & 0 & 0 & 0 & 0,09 & 0 & 0 & 0 & 0 & 0 & 0 & 0 \\
\hline Leitus fulvibarbis & Walker & leiful & 0 & 0 & 0 & 0 & 0,01 & 0 & 0 & 0 & 0 & 0 & 0 & 0,07 \\
\hline Staphylinidae & & & & & & & & & & & & & & \\
\hline Ocypus olens & Walker & ocyol & 0,03 & 0 & 0,03 & 0,02 & 0 & 0 & 0 & 0 & 0 & 0,33 & 0,03 & 0 \\
\hline Philonthus intermedius & Walker & phiint & 0,15 & 0,13 & 0,10 & 0,04 & 0,09 & 0,03 & 0,06 & 0 & 0,13 & 0 & 0,06 & 0,14 \\
\hline Indeterminate & Walker & & 0 & 0 & 0,03 & 0 & 0,01 & 0 & 0 & 0 & 0 & 0 & 0 & 0 \\
\hline Elateridae & & & & & & & & & & & & & & \\
\hline Adelocera murina & Walker & adelmur & 0 & 0 & 0 & 0,05 & 0,46 & 0,35 & 0,03 & 0,24 & 0 & 0 & 0 & 0 \\
\hline Agriotes gr-lineatus & Walker & agrgrl & 0,12 & 0 & 0 & 0,02 & 0,16 & 0,09 & 0 & 0,08 & 0 & 0 & 0 & 0 \\
\hline Athous haemoroides & Walker & athha & 0 & 0 & 0 & 0,04 & 0,09 & 0,03 & 0,03 & 0 & 0 & 0 & 0 & 0 \\
\hline Geotrupidae/Scarabidae & & & & & & & & & & & & & & \\
\hline Aphodius spp & Burrower & aphod & 0,18 & 0,19 & 0,15 & 0 & 0 & 0 & 0 & 0 & 0 & 0 & 0,03 & 0,29 \\
\hline Cetaunia aurata & Walker & cetaur & 0 & 0 & 0 & 0 & 0,08 & 0,62 & 0 & 0 & 0 & 0 & 0 & 0 \\
\hline Cetonia morio & Walker & cetmor & 0 & 0 & 0 & 0 & 0,01 & 0,06 & 0,06 & 0 & 0 & 0 & 0 & 0 \\
\hline Geotrupes pyreneaeus & Burrower & geopyr & 0 & 0 & 0 & 0,13 & 0,04 & 0,12 & 0,03 & 0 & 0 & 0 & 0 & 0 \\
\hline Onthophagus spp & Burrower & ontho & 0 & 0 & 0,05 & 0 & 0,03 & 0 & 0 & 0 & 0 & 0 & 0 & 0,21 \\
\hline Rhyzotroglus aestivus & Walker & rhyaes & 0 & 0 & 0 & 0 & 0,47 & 0,35 & 0 & 0 & 0 & 0 & 0 & 0 \\
\hline Typhoeus typhoeus & Burrower & typtyp & 0,29 & 0 & 0,05 & 0,02 & 0 & 0 & 0 & 0 & 0 & 0 & 0,29 & 0,29 \\
\hline Cucurlionidae & & & & & & & & & & & & & & \\
\hline Indeterminate & Walker & cuccur & 0,03 & 0 & 0,05 & 0,02 & 0,07 & 0,03 & 0,03 & 0,16 & 0 & 0 & 0,03 & 0,14 \\
\hline Tachyphloeus spp & Walker & cucur & 0,03 & 0 & 0,15 & 0 & 0,03 & 0 & 0 & 0 & 0,08 & 0 & 0 & 0 \\
\hline Otiorhynchus spp & Walker & cucur & 0,06 & 0,13 & 0 & 0,04 & 0,06 & 0 & 0,09 & 0,14 & 0,13 & 0 & 0 & 0 \\
\hline Tenebrionidae & & & & & & & & & & & & & & \\
\hline Opatrum sabulosum & Walker & opasab & 0 & 0 & 0 & 0,02 & 0,04 & 0,04 & 0 & 0 & 0 & 0 & 0 & 0 \\
\hline Nalassus laevioctostriatus & Walker & nallae & 0,06 & 0,06 & 0,05 & 0,07 & 0,17 & 0,12 & 0,06 & 0,05 & 0,13 & 0 & 0,03 & 0,07 \\
\hline Histeridae & & & & & & & & & & & & & & \\
\hline $\begin{array}{l}\text { Hister quadrimaculata } \\
\text { Oedemeridae }\end{array}$ & Walker & hisqua & 0 & 0 & 0 & 0,09 & 0,37 & 0,06 & 0 & 0 & 0 & 0 & 0 & 0 \\
\hline $\begin{array}{l}\text { Oedemeridae } \\
\text { Psilotrix viridescens }\end{array}$ & Other & Psivir & 0 & 0 & 0 & 0,02 & 0,02 & 0,06 & 0 & 0 & 0 & 0 & 0 & 0 \\
\hline Indeterminate adult & Walker & & 0,06 & 0 & 0,08 & 0,16 & 0,07 & 0,09 & 0 & 0,03 & 0,13 & 0,17 & 0,23 & 0 \\
\hline $\begin{array}{l}\text { Indeterminate larvae } \\
\text { DERMAPTERA }\end{array}$ & Burrower & larcol & 0,24 & 0,06 & 0,30 & 0,41 & 0,10 & 0,32 & 0,06 & 0 & 0 & 0 & 0,10 & 0,07 \\
\hline $\begin{array}{l}\text { Forficula auricularia } \\
\text { HYMENOPTERA }\end{array}$ & Walker & forau & 0,03 & 0 & 0 & 0,02 & 0,04 & 0,09 & 0 & 0 & 0 & 0 & 0,03 & 0 \\
\hline Eumenidae & Other & hymeum & 0 & 0 & 0 & 0 & 0,01 & 0 & 0 & 0 & 0,04 & 0 & 0 & 0 \\
\hline Formicidae & & & & & & & & & & & & & & \\
\hline Eggs & Burrower & foregg & 0 & 0 & 0 & 0,02 & 0,01 & 0,06 & 0,31 & 0,22 & 0,08 & 0 & 0 & 0 \\
\hline Lasius flavus & Walker & lasfla & 0,03 & 0 & 0 & 0,09 & 0,16 & 0,29 & 0,97 & 0,86 & 0,42 & 0,67 & 0,39 & 0 \\
\hline Myrmica sabuleti & Walker & myrsab & 0 & 0 & 0,03 & 0,02 & 0,04 & 0,12 & 0,13 & 0,16 & 0,29 & 0 & 0 & 0 \\
\hline DIPTERA & & & & & & & & & & & & & & \\
\hline Inderterminate adult & Walker & dipt & 0 & 0 & 0 & 0 & 0 & 0,03 & 0 & 0 & 0 & 0 & 0 & 0,07 \\
\hline Tipulidae larvae & Burrower & lartip & 0,59 & 0,94 & 0,85 & 0,38 & 0,03 & 0 & 0 & 0 & 0 & 0 & 0,32 & 0,14 \\
\hline
\end{tabular}


Table 2: Relative importance of each of three prey classes in chough diet on island of Ouessant

\begin{tabular}{|c|c|c|c|}
\hline & April to June & July to October & November to March \\
\hline Burrower & 5.0 & 1.5 & 46.6 \\
\hline Walker & 94.8 & 98.1 & 49.5 \\
\hline Other & 0.2 & 0.4 & 3.9 \\
\hline
\end{tabular}

Table 3. Model selection for juvenile survival variation, $\Delta \mathrm{AICc}$. is the difference of AIC between the considered model and the best one.

\begin{tabular}{|c|c|c|c|c|c|}
\hline Model & $\begin{array}{c}\text { AIC } \\
\mathrm{c}\end{array}$ & $\begin{array}{c}\Delta \\
\mathrm{AIC}_{\mathrm{c}}\end{array}$ & $\begin{array}{l}\mathrm{N} \\
\mathrm{P}\end{array}$ & Deviance & $\begin{array}{c}\text { AICc } \\
\text { Weight }\end{array}$ \\
\hline $\begin{array}{l}\mathrm{S}[\text { month+ } \\
\text { year] }\end{array}$ & $\begin{array}{c}249 . \\
49\end{array}$ & 0.00 & 18 & 37.32 & 0.98 \\
\hline$S[$ month $]$ & $\begin{array}{c}267 . \\
08\end{array}$ & 7.59 & 13 & 55.61 & 0.02 \\
\hline $\mathrm{S}$ [year] & $\begin{array}{c}333 . \\
25\end{array}$ & $\begin{array}{c}73.7 \\
6\end{array}$ & 6 & 136.39 & 0.00 \\
\hline $\mathrm{S}[]$. & $\begin{array}{c}343 . \\
52\end{array}$ & $\begin{array}{c}84.0 \\
3\end{array}$ & 1 & 156.83 & 0.00 \\
\hline $\begin{array}{l}S[\text { month* } \\
\text { year] }\end{array}$ & $\begin{array}{c}371 . \\
49\end{array}$ & $\begin{array}{c}112 . \\
00\end{array}$ & 78 & 0.00 & 0.00 \\
\hline
\end{tabular}


Figure 1: Diet of the chough in Ouessant expressed as the proportion of the total number of individuals counted in the faecal samples analysed each month.

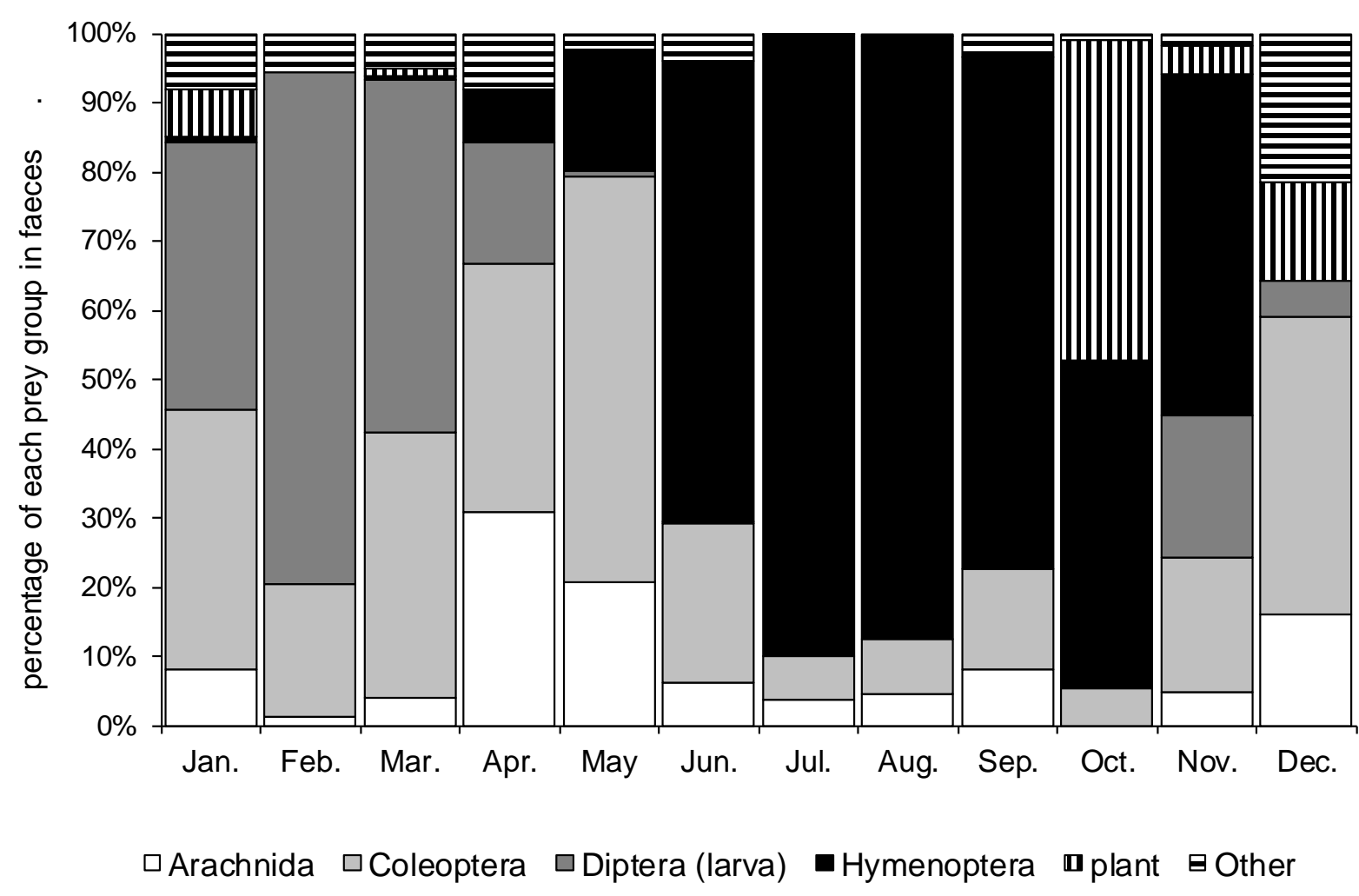


Figure 2: PCA axis 1 and axis 2 scores indicating the seasonal breackdown of Chough diet composition by (a) month and (b) prey taxa.

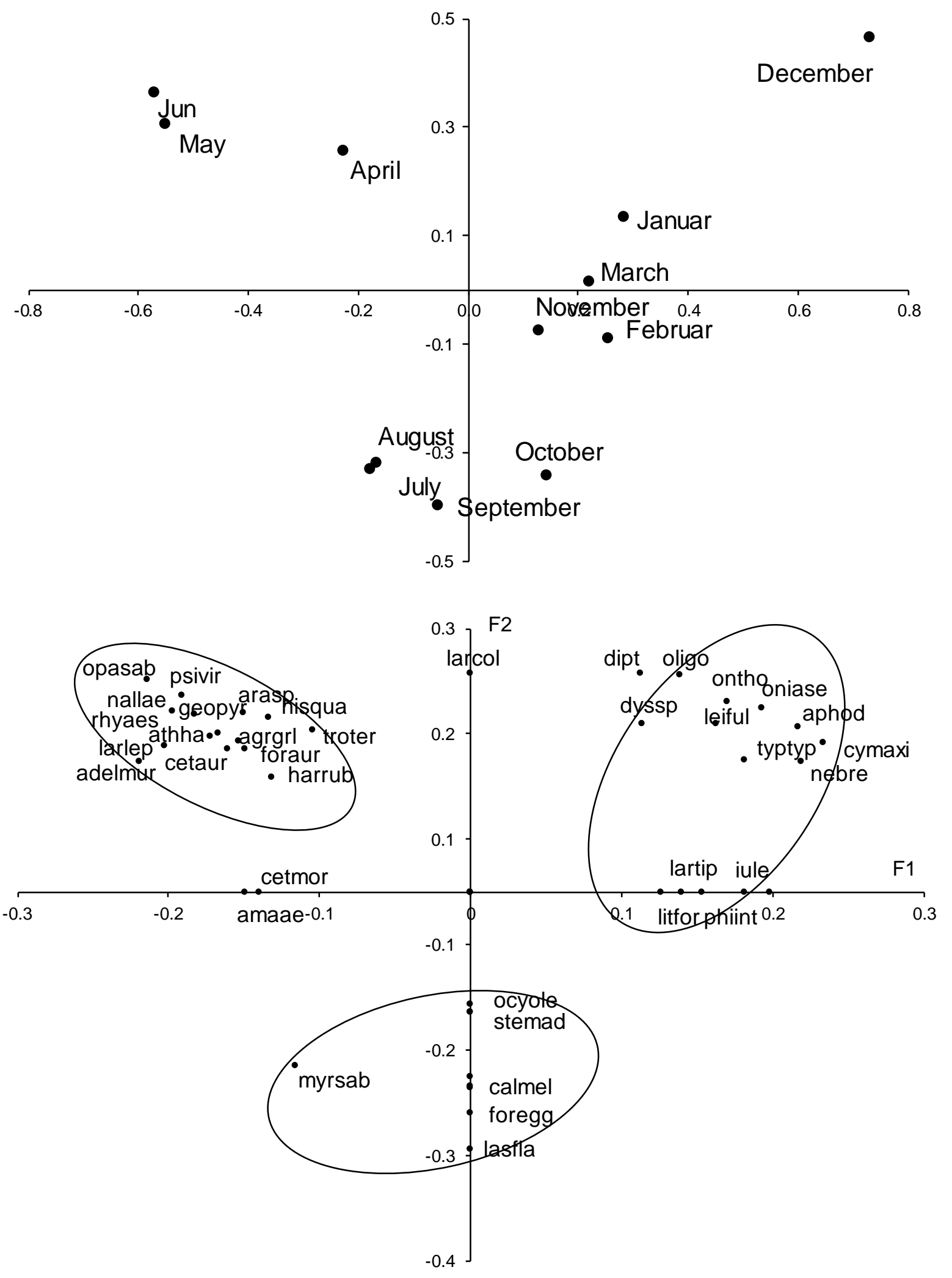


Figure 3: Monthly variation in chough prey biomass in 1996 (dark square data drawn from six pitfall locations) and 1997 (dark circles data drawn from one pitfall location).

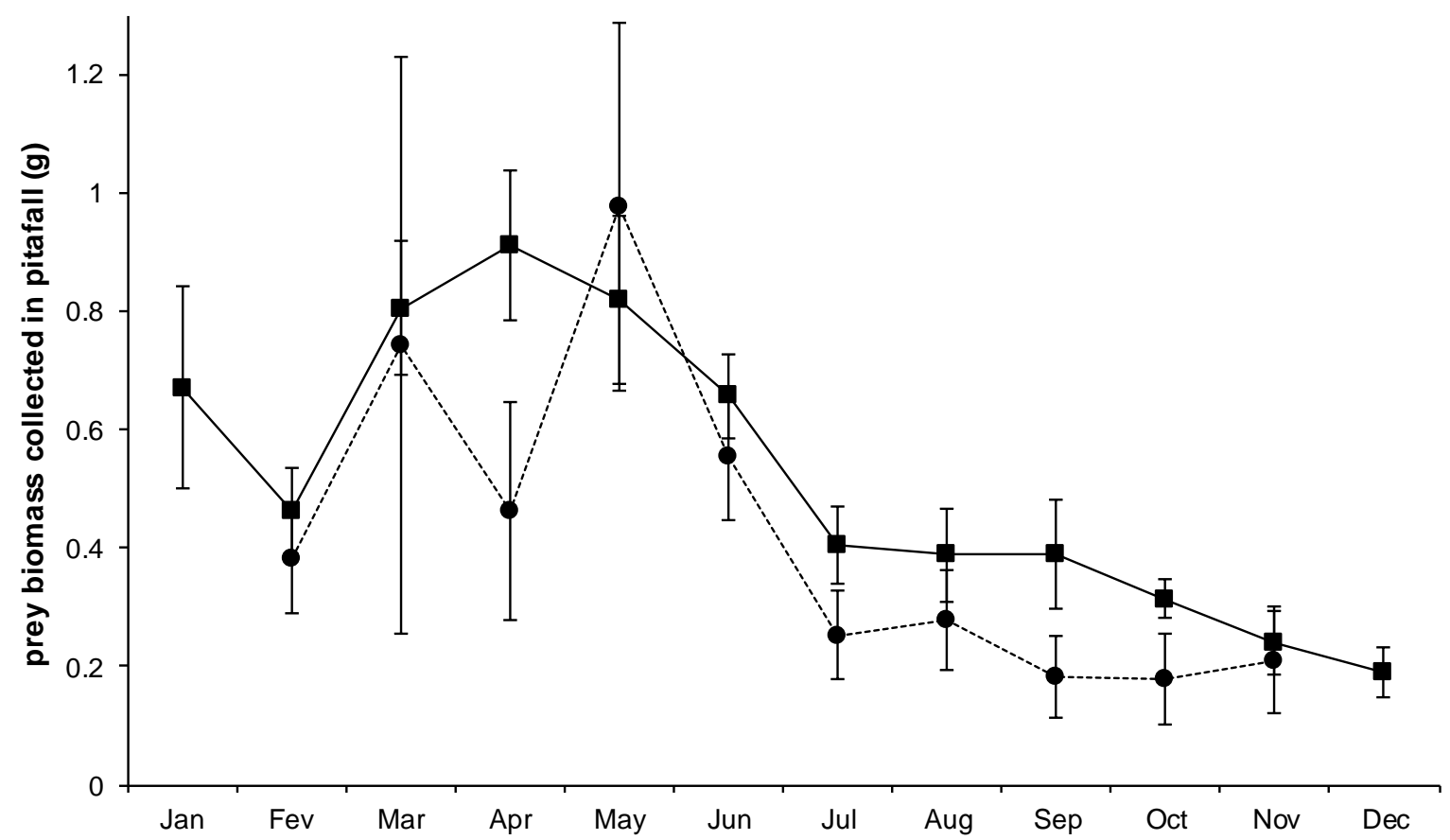


Figure 4: Monthly variation in chough juvenile survival on the island of Ouessant

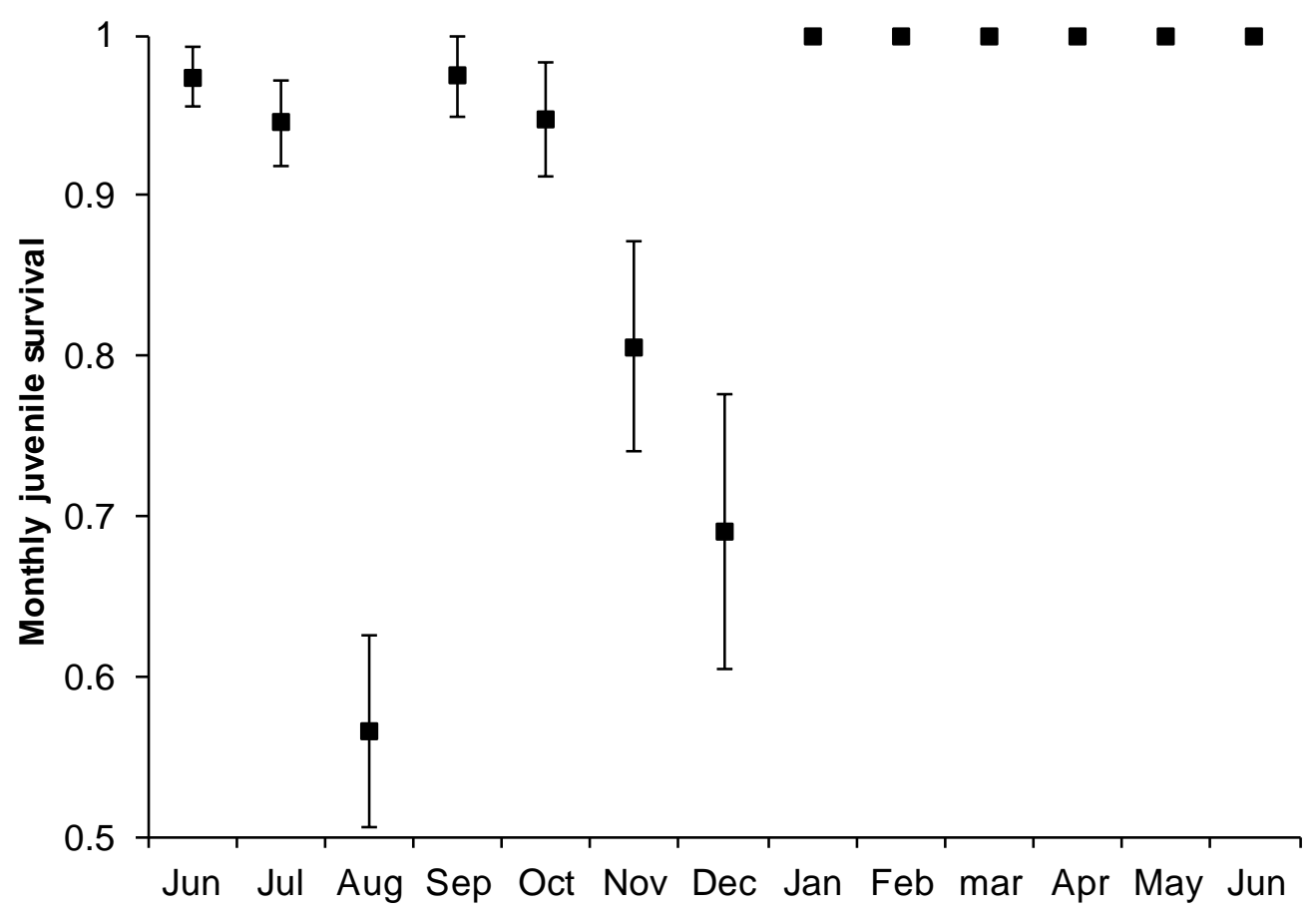


Figure 5: Relationship between fledging success and biomass collected in May on chough foraging habitat.

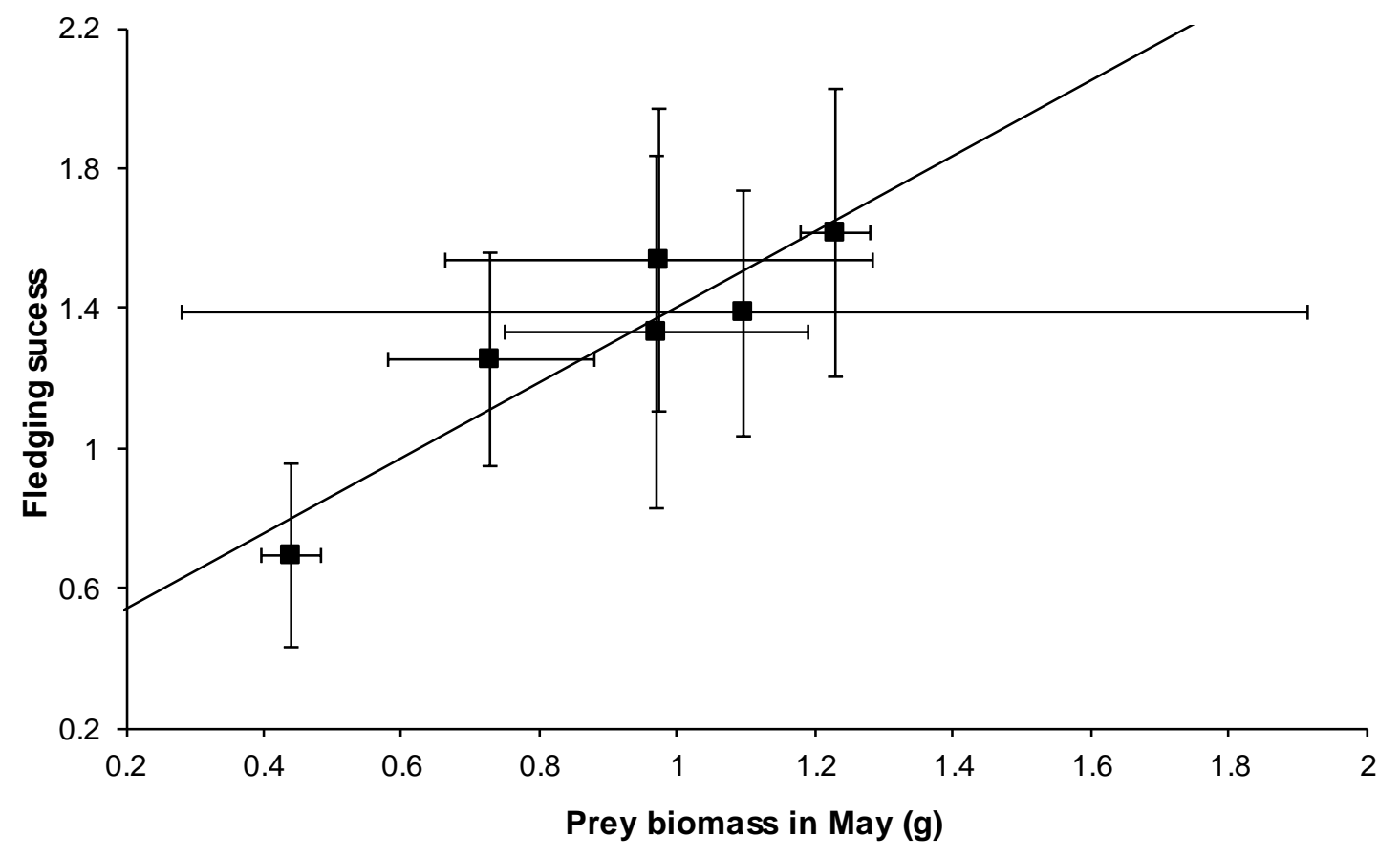

